\title{
KEGAGALAN ASESMEN AUTENTIK PADA PELAJARAN PENDIDIKAN AGAMA ISLAM DI SEKOLAH DASAR DAN MENENGAH
}

\author{
Agung Prihantoro*) \\ Program Studi Pendidikan Agama Islam \\ Fakultas Agama Islam Universitas Cokroaminoto Yogyakarta \\ aprihantoro@ucy.ac.id \\ *Penulis koresponden \\ \begin{tabular}{|l|l|l|}
\hline Diajukan: 27-04-2021 & Diterima: 21-05-2021 & Diterbitkan: 12-06-2021 \\
\hline
\end{tabular}
}

\begin{abstract}
The article aimed to (1) describe how failure of the application of authentic assessment of Islamic education in Indonesia's primary and junior schools was, (2) explain why the failure happened, and (3) explain what the failure implied. Using the systematic literature review, the article investigated 27 researches on authentic assessment practices. The conclusions are that (1) the failure were proved in very few features of authentic assessment at the practices, because (2) the teachers of Islamic education did not understand authentic assessment and in turn because campaign and training of authentic assessment were a minimum. (3) The failure implied in untrained studenrs to apply their acquired knowledge, higher order thinking skills and attitude in real life, identify and solve Muslim's complex problems, collaborate and construct knowledge.

Keywords: authentic assessment, Islamic education, primary school, junior school
\end{abstract}

\begin{abstract}
Abstrak: Artikel ini bertujuan untuk (1) mendeskripsikan bagaimana kegagalan pelaksanaan AA pada pelajaran PAI di sekolah dasar dan menengah di Indonesia, (2) menjelaskan mengapa kegagalan tersebut terjadi dan (3) menjelaskan apa implikasi dari kegagalan itu. Dengan metodologi penelitian pustaka sistematis (systematic literature review), artikel ini telah meneliti 27 pustaka hasil penelitian tentang praktik AA. Artikel ini berkesimpulan bahwa (1) kegagalan pelaksanaan AA itu berupa sedikitnya karakteristik AA yang terdapat dalam praktik-praktik AA tersebut. (2) Kegagalan ini disebabkan guru-guru PAI-nya tidak memahami AA, karena kurangnya sosialisasi dan pelatihan AA. (3) Kegagalan ini berimplikasi pada siswa-siswa yang tidak terdidik untuk menerapkan pengetahuan, keterampilan berpikir tingkat tinggi dan sikap dalam kehidupan riil, mengidentifikasi dan menyelesaikan masalahmasalah umat Islam yang kompleks, berkolaborasi, dan mengonstruksi pengetahuan.
\end{abstract}

Kata kunci: asesmen autentik, pendidikan agama Islam, sekolah dasar, sekolah menengah 


\section{A. Pendahuluan}

Pelaksanaan penilaian atau asesmen autentik (AA) pada mata pelajaran Pendidikan Agama Islam (PAI) di sekolah dan madrasah di Indonesia boleh dikatakan gagal meskipun pemerintah sudah mengundangkan peraturan dan memberikan petunjuk teknis pelaksanaan AA. ${ }^{1}$ Sebagian guru PAI tidak mengerti dan tidak melaksanakan AA. ${ }^{2}$ Penerapan AA dalam pelajaran PAI di sekolah-sekolah dasar (SD) atau madrasah ibtidaiyah (MI), menengah pertama $(\mathrm{SMP})^{3}$ atau madrasah tsanawiyah (MTs), menengah (SMA) dan menengah kejuruan (SMK) negeri, ${ }^{4}$ dan swasta $^{5}$ berjalan secara tidak efektif dan tidak maksimal. Dalam melakukan AA, guru PAI tidak menggunakan memberikan tugas proyek yang autentik kepada siswa, ${ }^{6}$ padahal tugas proyek yang autentik ${ }^{7}$ dengan kerja kelompok merupakan komponen penting dalam AA. Tak hanya bermasalah di sekolah, pelaksanaan AA juga menemui problem

${ }^{1}$ Kemenag RI, Surat Keputusan Direktur Jenderal Pendidikan Islam Nomor 5161 Tahun 2018 Tentang Petunjuk Teknis Hasil Belajar pada Madrasah Ibtidaiyah, 2018; Kemenag RI, Surat Keputusan Direktur Jenderal Pendidikan Islam Nomor 5162 Tahun 2018 Tentang Petunjuk Teknis Hasil Belajar pada Madrasah Tsanawiyah, 2018; Kemenag RI, Surat Keputusan Direktur Jenderal Pendidikan Islam Nomor 3751 Tahun 2018 Tentang Petunjuk Teknis Hasil Belajar pada Madrasah Aliyah, 2018.

2 Jainuri Berampu, "Penerapan Penilaian Autentik Dalam Penilaian Aspek Sikap Bidang Studi PAI di MTs Negeri 2 Medan" (Universitas Islam Negeri Sumatera Utara, 2016).

3 Irfan Murdianto Yudistiro, "Implementasi Penilaian Autentik pada Mata Pelajaran Pendidikan Agama Islam dan Budi Pekerti (Studi Multisitus di SMP Negeri 10 Malang dan SMP Brawijaya Smart School Malang)" (Universitas Islam Negeri Maulana Malik Ibrahim Malang Indonesia, 2019).

4 Efi Tri Astuti, "Problematika Implementasi Penilaian Autentik Kurikulum 2013 Dalam Pembelajaran Pendidikan Agama Islam Di SD Negeri Ploso I Pacitan," Al-Idaroh 1, no. 2 (2017): 18-41; Riri Susanti, "Implementasi Penilaian Autentik Pada Mata Pelajaran Pendidikan Agama Islam Dan Budi Pekerti," al-fikrah: Jurnal Manajemen Pendidikan 4, no. 1 (2016): 55; Abdullah, "Implementasi Penilaian Autentik Kurikulum 2013 Pada Pembelajaran Pendidikan Agama Islam Di Madrasah Tsanawiyah Negeri 2 Palangka Raya," FITRAH:Jurnal Kajian Ilmu-ilmu Keislaman 2, no. 2 (2017): 59.

5 Dika Setiawan, "Pendekatan Saintifik Dan Penilaian Autentik Untuk Meningkatkan Mutu Pembelajaran Pendidikan Agama Islam," AL-ASASIYYA: Journal Of Basic Education 1, no. 2 (2017): 34-46.

6 Halimi Ansor, "Strategi Penilaian Autentik Kurikulum 2013 Pada Mata Pelajaran Pendidikan Agama Islam Dan Budi Pekerti (Studi Kasus Di SMP Negeri 1 Pabuaran Kabupaten Cirebon)," Oasis: Jurnal Ilmiah Kajian Islam 3, no. 1 (2018): 5772.

7 Terhi Nurmikko-Fuller dan Ian E. Hart, "Constructive alignment and authentic assessment in a media-rich undergraduate course," Educational Media International oo, no. oo (2020): 1-16. 


\section{Kegagalan Asesmen Autentik pada \\ Pelajaran PAI di Sekolah Dasar dan Menengah}

pada jenjang perguruan tinggi. ${ }^{8}$ Ketidakefektifan, ketidakmaksimalan, ketiadaan komponen penting dalam AA, dan kebermasalahan praktik AA dalam berbagai jenjang pendidikan di Indonesia mengindikasikan bahwa pelaksanaan AA bisa dikatakan tidak cukup berhasil.

Penelitian-penelitian tentang pelaksanaan dan konsep AA pada mata pelajaran PAI di sekolah atau madrasah di Indonesia umumnya berlokasi di 1-3 sekolah atau madrasah ${ }^{9}$ dan menggunakan sumbersumber referensi lokal. $^{10}$ Penelitian-penelitian di 1-3 sekolah atau madrasah memiliki kesimpulan yang tingkat generalisasi rendah, tetapi lebih detail. Sementara itu, penelitian-penelitian dengan hanya referensireferensi lokal tidak merujuk pada perkembangan-perkembangan terbaru yang dipaparkan pada referensi-referensi internasional berbahasa Inggris. Sebenarnya, ada penelitian di banyak lokasi atau dengan banyak responden, tetapi menggunakan referensi lokal atau sedikit referensi internasional. ${ }^{11}$ Sebaliknya, ada sejumlah penelitian dengan referensireferensi internasional, tetapi lokasi penelitiannya hanya di $1-3$ sekolah

8 Anis Marfuah dan Febriza Febriza, "Penilaian Autentik pada Pembelajaran Pendidikan Agama Islam (PAI) di Sekolah dan Perguruan Tinggi," Fondatia 3, no. 2 (2019): 35-58.

9 Saiful Arif, "Penerapan Penilaian Autentik Pada Mata Pelajaran PAI Di SMPN 1 Pamekasan," NUANSA: Jurnal Penelitian Ilmu Sosial dan Keagamaan Islam 11, no. 2 (2014): 235-262; Nanang Kosim, "Implementasi Penilaian Autentik Kurikulum 2013 dalam Mata Pelajaran Pendidikan Agama Islam dan Budi Pekerti di SMPN 6 Surabaya" (Universitas Islam Negeri Sunan Ampel Surabaya, 2014); Novialdi Putra, "Penilaian Autentik Mata Pelajaran Pendidikan Agama Islam Dan Budi Pekerti Di SMP Negeri 4 Pariaman," al-fikrah: Jurnal Manajemen Pendidikan 3, no. 2 (2016): 203; Hadi Nurrohim, "Implementasi Penilaian Otentik Bidang Studi PAI dan Budi Pekerti di SMAN Dempet Jawa Tengah," At-Tajdid 01, no. 02 (2017); Aprilia Tri Sugiarti, "Penerapan Penilaian Autentik dalam Pembelajaran Pendidikan Agama Islam Kelas X di SMAN 3 Yogyakarta" (Universitas Islam Negeri Sunan Kalijaga Yogyakarta, 2016); Sulistiati Sulistiati, "Kompetensi Guru Pendidikan Agama Islam dalam Penilaian Autentik di SMA Negeri 1 Arga Makmur,” Al-Bahtsu: Jurnal Penelitian Pendidikan Islam 2, no. 1 (2017): 143-154.

10 Zakiyah Wulansari, "Pendidikan Agama Islam Dan Budi Pekerti Kurikulum 2013," Attarbiyah I, no. 1 (2016): 29-58; Muzlikhatun Umami, "Penilaian Autentik Pembelajaran Pendidikan Agama Islam dan Budi Pekerti dalam Kurikulum 2013," Jurnal Kependidikan 6, no. 2 (2018): 222-232.

${ }^{11}$ Suparjo, "Dinamika Perubahan Paradigma Pendidikan: Studi tentang Kesiapan Guru Pendidikan Agama Islam di SD/MI di Wilayah Kabupaten Banyumas dalam Menerapkan Pendekatan Pembelajaran Saintifik dan Penilaian Otentik Kurikulum 2013," Jurnal Penelitian Agama 15, no. 2 (2014). 
atau madrasah. ${ }^{12}$ Di sini terdapat kekosongan penelitian (reesearch gap), yakni penelitian AA pada PAI yang kesimpulannya mempunyai tingkat generalisasi tinggi dan yang merujuk pada perkembangan-perkembangan terbaru dalam bidang AA di referensi-referensi internasional terkini.

Artikel ini merupakan hasil penelitian yang mengisi kekosongan penelitian tersebut. Kesimpulan dalam artikel ini memiliki tingkat generalisasi yang lebih tinggi daripada kesimpulan dalam penelitian yang dilakukan di sedikit sekolah atau madrasah saja. Artikel ini juga mengacu pada referensi-referensi internasional terbaru untuk menggali pemikiranpemikiran terkini dan membaca bagaimana pelaksanaan AA pada pelajaran PAI di Indonesia. Maka, artikel bertujuan untuk (1) mendeskripsikan bagaimana kegagalan pelaksanaan AA pada pelajaran PAI di sekolah-sekolah dasar dan menengah di Indonesia, (2) menjelaskan mengapa kegagalan tersebut terjadi dan (3) menjelaskan apa implikasi dari kegagalan pelaksanaan AA pada pelajaran PAI di sekolah-sekolah dasar dan menengah.

Argumen dalam artikel ini ialah bahwa pelaksanaan AA pada pelajaran PAI di sekolah-sekolah dasar dan menengah di Indonesia gagal ketika ditakar dengan ukuran-ukuran AA yang komprehensf. Ukuranukuran AA yang komprehensf dari literatur-literatur internasional tentang AA mencakup konteks, tugas untuk siswa, aktivitas siswa, indikator asesmen, dan umpan balik untuk siswa, yang di dalamnya terdapat 23 karakteristik. Dua puluh tiga karakteristik AA itu ialah (1) konteks fisik/virtual, (2) konteks sosial, (3) tugas yang berupa kegiatan riil, (4) tugas yang menyelesaikan masalah (problem solving), (5) tugas yang menantang, (6) tugas yang kompleks, (7) tugas yang tidak terstruktur, (8) tugas yang membutuhkan waktu lama (beberapa pekan) untuk menyelesaikannya, (9) siswa menerapkan keterampilan berpikir tingkat tinggi, (10) siswa menerapkan pengetahuan, keterampilan dan sikap, (11)

${ }^{12}$ Susanti, "Implementasi"; Alhamuddin, "Implementasi Penilaian Otentik dalam Pembelajaran PAI Berbasis Multiple Intelligences di Sekolah Dasar Islam Terpadu Buahati Jakarta," Ta'dib 5, no. 1 (2016); Yudistiro, "Implementasi Penilaian Autentik pada Mata Pelajaran Pendidikan Agama Islam dan Budi Pekerti (Studi Multisitus di SMP Negeri 10 Malang dan SMP Brawijaya Smart School Malang).” 


\section{Kegagalan Asesmen Autentik pada \\ Pelajaran PAI di Sekolah Dasar dan Menengah}

siswa mengambil keputusan, (12) siswa berpartisipasi dalam kegiatan riil, (13) siswa kreatif, (14) siswa berkolaborasi, (15) siswa menilai diri sendiri (self-assessment), (16) siswa mempresentasikan kinerja/produknya secara lisan atau tulisan, (17) terdapat indikator untuk menilai produk siswa, (18) terdapat indikator untuk menilai unjuk kerja siswa, (19) terdapat rubrik untuk menilai produk/unjuk kerja siswa, (20) terdapat beragam indikator untuk menilai aktivitas belajar, (21) AA menjadikan siswa lebih aktif belajar, (22) AA mengurangi plagiarisme, dan (23) siswa mendapatkan umpan balik untuk meningkatkan unjuk kerja/produknya. Dua puluh tiha karakteristik AA ini menjadi takaran untuk mengukur kegagalan pelaksanaan AA di sekolah-sekolah dasar di Indonesia. Kegagalan tersebut bersumber dari beberapa penyebab dan juga berimplikasi pada sejumlah hal dalam PAI dan kaum Muslim.

Untuk menjelaskan hasil-hasil dan argumen-argumen penelitian ini, diperlukan suatu kerangka teoretis. Kerangka teoretis ini mencakup teori AA, kritik dan hambatan penerapan AA, dan tujuan PAI. Teori AA meliputi pengertian, tujuan, prinsip, komponen, dan langkah penerapan AA. Para ahli mendefinisikan AA dalam beragam kalimat yang intinya adalah suatu bentuk asesmen yang meminta siswa untuk mengerjakan tugas-tugas atau proyek-proyek yang sesuai dengan pekerjaan-pekerjaan dalam kehidupan nyata sehingga siswa berpartisipasi dalam aktivitas kehidupan riil ${ }^{13}$ dan benar-benar menerapkan pengetahuan dan keterampilan-keterampilan penting, ${ }^{14}$ keahlian, keterampilanketerampilan berpikir tingkat tinggi (higher order thinking skills) dan penyelesaian masalah (problem-solving skills) ${ }^{15}$ dan kreativitas yang telah

13 Brenda C. Litchfield dan John V. Dempsey, "Authentic Assessment of Knowledge, Skills, and Attitudes," New Directions For Teaching And Learning 142 (2015).

14 Jon Mueller, "Authentic Assessment Toolbox."

15 J. Herrington dan A. Herrington, "Authentic conditions for authentic assessment: Aligning task and assessment," in Proceedings of the 29th HERDSA Annual Conference (Milperra: Higher Education Research and Development Society of Australasia, Inc, 2006). 
siswa pelajari dalam aktivitas belajar mengajar. ${ }^{16}$ Tugas-tugas AA tersebut lebih praktis dan menantang ketimbang tugas-tugas dalam asesmen tradisional, ${ }^{17}$ kompleks, tidak terstruktur, dan mendorong siswa untuk bekerja keras dalam waktu yang lama, saling berkolaborasi, melakukan penilaian dan mengambil keputusan. ${ }^{18}$ Penerapan atau transfer pengetahuan, sikap, keahlian, keterampilan-keterampilan berpikir tingkat tinggi dan penyelesaian masalah, dan kreativitas siswa ke kehidupan nyata ini berarti bahwa siswa menunjukkan suatu kinerja (performance) atau $\operatorname{praktik}^{19}$ atau menghasilkan suatu produk ${ }^{20}$ yang relevan dengan mata pelajarannya dan usia siswa. Jadi, AA meminta siswa untuk menyelesaikan tugas-tugas autentik yang praktis, menantang, kompleks, tidak terstruktur dan sesuai dengan pekerjaan-pekerjaan riil dalam kehidupan sehari-hari atau di tempat kerja yang mendorong siswa untuk bekerja keras dalam waktu yang lama, saling berkolaborasi, melakukan penilaian dan mengambil keputusan. Sehingga, siswa betul-betul mengaplikasikan pengetahuan, kreativitas, keahlian, keterampilanketerampilan berpikir tingkat tinggi dan penyelesaian masalah. Siswa menunjukkan suatu kinerja atau menghasilkan suatu produk yang relevan dengan mata pelajarannya dan sesuai dengan usianya. Siswa memproduksi, bukan mareproduksi, pengetahuan, dan semua aktivitas siswa tersebut dinilai dengan beragam, bukan satu, indikator. ${ }^{21}$

Pada jenjang perguruan tinggi, AA-beserta authentic learning (pembelajaran autentik, PA)-bertujuan untuk membuat hasil aktivitas

16 Kevin Ashford-Rowe, Janice Herrington, dan Christine Brown, "Establishing the critical elements that determine authentic assessment," Assessment and Evaluation in Higher Education 39, no. 2 (2014): 205-222.

17 Jan Herrington dan Anthony Herrington, "Authentic assessment and multimedia: How university students respond to a model of authentic assessment," International Journal of Phytoremediation 21, no. 1 (1998): 305-322.

18 Jan Herrington dan Ron Oliver, "An instructional design framework for authentic learning environments," Educational Technology Research and Development 48, no. 3 (2000): 23-48.

19 Melenie Archer, Dawn A. Morley, dan Jean-Baptiste R. G. Souppez, "Real World Learning and Authentic Assessment," in Applied Pedagogies for Higher Education Real World Learning and Innovation across the Curriculum (Cham: Palgrave Macmillan, 2021).

${ }_{20}$ Ashford-Rowe, Herrington, dan Brown, "Establishing"

${ }^{21}$ Herrington dan Oliver, "An instructional" 


\section{Kegagalan Asesmen Autentik pada Pelajaran PAI di Sekolah Dasar dan Menengah}

belajar mengajar (learning and teaching outcomes) selaras dengan kebutuhan dunia industri. ${ }^{22}$ Ini selaras dengan pernyataan Archer, Morley dan Souppez bahwa AA bertujuan untuk membangun jaringan kerja, meningkatkan harapan kerja, dan memberikan pengalaman industri yang relevan dan terbaru. ${ }^{23}$ Namun, industrialisasi tujuan AA dan perguruan tinggi ini mendapat kritik keras. ${ }^{24}$ Pada jenjang sekolah, diharapkan lulusannya, bukan hanya memiliki pengetahuan, melainkan juga menerapkannya dan bertindak dalam kehidupan nyata. ${ }^{25}$ Sementara itu, ahli-ahli lain menyebut tujuan AA hanya sampai pada aktivitas belajar, yakni untuk meningkatkan produktivitas, ${ }^{26}$ keaktifan belajar, ${ }^{27}$ pemahamanan dan kreativitas dan menurunkan plagiarisme. ${ }^{28}$ Jadi, AA pada level sekolah dasar dan menengah dan perguruan tinggi bertujuan jangka pendek dalam lingkup aktivitas belajar mengajar dan juga jangka panjang dalam lingkungan kerja dan lingkungan kehidupan lain.

Para ahli juga menggariskan prinsip-prinsip AA. Ashford-Rowe, Herrington dan Brown secara cukup lengkap mengidentifikasi 8 prinsip atau ciri $\mathrm{AA}^{29}$ (1) Tugas untuk siswa harus menantang. (2) AA menghasilkan kinerja atau produk yang menyelesaikan masalah. (3) Siswa mentransfer dan menerapkan pengetahuan, keterampilan dan sikapnya dalam kehidupan nyata. (4) AA melibatkan metakognisi dalam bentuk asesmen diri (self-evaluation, self-assessment) dan refleksi kritis (critical

22 Ashford-Rowe, Herrington, dan Brown, "Establishing"

23 Archer, Morley, dan Souppez, "Real"

24 Abdullah Sahin, "Critical issues in islamic education studies: Rethinking islamic and western liberal secular values of education," Religions 9, no. 11 (2018).

25 Herrington dan Oliver, "An instructional"

26 Alison Penelope Bosnakis, "The Bigger Picture: Authentic Assessment and Visual Literacy: Applying a Nordic Approach to an Australian Context," in Reflective Practice in Teaching Pre-service Teachers and the Lens of Life Experience, ed. Gretchen Geng et al. (Singapore: Springer Singapore, 2019).

27 Mueller, “Authentic Assessment Toolbox"; Edmund Jun Meng Chong et al., "Improvement of learning domains of nursing students with the use of authentic assessment pedagogy in clinical practice," Nurse Education in Practice 20 (2016): 125130.

28 Ryan Jopp, “A case study of a technology enhanced learning initiative that supports authentic assessment," Teaching in Higher Education o, no. O (2019): 1-17; Cath Ellis et al., "Does authentic assessment assure academic integrity? Evidence from contract cheating data," Higher Education Research and Development o, no. o (2019): 116.

29 Ashford-Rowe, Herrington, dan Brown, "Establishing” 
reflection) atau refleksi diri (self-reflection) atas apa yang telah siswa pelajari untuk meningkatkan kinerja dan produknya. (5) AA menentukan apa saja (pengetahuan, keterampilan, sikap dan lain-lainnya) yang perlu dipelajari siswa dalam rangka menyelesaikan tugas autentik atau pekerjaan riil. Di sini, guru menilai, bukan hanya kinerja atau produk akhir siswa, melainkan juga proses-proses siswa dalam mencapai kinerja akhir atau menghasilkan produk akhir tersebut. (6) Situasi, kondisi, tempat dan alat asesmen dibuat sesuai dengan kehidupan nyata secara optimal atau bahkan merupakan kehidupan nyata itu sendiri di mana kinerja atau produk siswa ditunjukkan atau dibuat. (7) Guru memberikan umpan balik (feedback) kepada siswa, dan siswa-siswa juga saling memberi dan menerima umpan balik untuk menyempurnakan kinerja atau produk siswa. (8) AA mengharuskan para siswa saling berkolaborasi.

Ketika 8 prinsip ini diterapkan dalam simulasi daring, ternyata hanya 7 prinsip yang berlaku dengan tambahan 4 sub-prinsip pada prinsip. Satu prinsip tidak berlaku, yakni prinsip 8 tentang kolaborasi. Empat sub-prinsip tersebut merupakan sub-prinsip nomor 6, yaitu (a) lingkungannya mendalam dan detail, (b) kontennya melibatkan emosi siswa, (c) waktunya dibatasi, dan (d) terdapat unsur unpredictability (tidak dapat diprediksi). Newmann, King dan Carmichae ${ }^{30}$ menambahkan 3 prinsip, yakni (1) siswa mengonstruksi pengetahuan, (2) siswa melakukan penelitian dan (3) siswa menghasilkan wacana, produk dan kinerja yang manfaatnya sampai di luar sekolah.

Pengertian-pengertian dan prinsip-prinsip AA tersebut diwadahi dalam komponen-komponen dan langkah-langkah pelaksanaan AA. Gulikers, Bastiaens dan Kirschner mengajukan 5 dimensi AA, yakni tugas, konteks fisik atau virtual, konteks sosial, dan hasil. ${ }^{31}$ Villarroel, Bloxham, Bruna, Bruna dan Herrera-Seda mencatat 3 dimensi AA, yaitu realisme,

зо M. Bruce King, Fred M. Newmann, dan Dana L. Carmichael, "Authentic intellectual work: Common standards for teaching social studies," Social Studies Today: Research and Practice: Second Edition, no. April (2015): 53-64.

${ }^{11}$ P. Gulikers, J., Bastiaens, T., \& Kirschner, "A Five-Dimensional Framework for Authentic Assessment," Educational Technology Research and Development 52, no. 3 (2004): 67-86. 


\section{Kegagalan Asesmen Autentik pada \\ Pelajaran PAI di Sekolah Dasar dan Menengah}

tantangan kognitif dan penilaian evaluatif (evaluative judgement). ${ }^{32}$ Penilaiannya menggunakan rubrik dan portofolio selama siswa belajar dan berproses mengerjakan tugas atau proyek autentiknya ${ }^{33}$ dengan kriteria berbasis keterampilan (skill-based criteria) yang dipakai dalam banyak profesi. $^{34}$ Sementara itu, Herrington dan Oliver menyodorkan 4 komponen, yaitu konteks, peran siswa atau faktor siswa, aktivitas yang autentik atau faktor tugas, dan indikator. ${ }^{35}$ Selanjutnya, Villarroel dan kawan-kawan merumuskan 4 langkah pelaksanaan, yakni menentukan konteks kerja, mendesain AA, menilai siswa, dan memberikan umpan balik kepada siswa. ${ }^{36}$ Mueller menyajikan 4 tahap AA, yakni menentukan standar-standar capaian siswa, merancang tugas untuk siswa, menentukan kriteria kinerja atau produk siswa, dan membuat rubrik penilaian. ${ }^{37}$ Dengan merangkum pendapat-pendapat para ahli tersebut, maka karakteristik-karakteristik AA dikelompokkan ke dalam konteks, tugas untuk siswa, aktivitas siswa, indikator asesmen, dan umpan balik.

AA tidak lepas dari kelemahan, dan pelaksanaannya pun tidak luput dari hambatan. Kelemahan AA dan hambatan pelaksanaannya dikritik dan kemudian dijawab untuk menempatkan dan melakukan AA secara proporsional. Kritik pertama menyatakan bahwa validitas AA mengorbankan reliabilitas, dan jawaban atas kritik ini ialah bahwa reliabilitas dilihat bukan hanya dari perspektif psikometri, melainkan juga dari perspektif kebermanfaatannya dalam kehidupan nyata. ${ }^{38}$ Kedua, validitas AA juga dipertanyakan, dan untuk meningkatkan validitas dan juga reliabilitas AA, diperlukan kerangka konseptual dan kerangka praktis

$3^{2}$ Verónica Villarroel et al., "Authentic assessment: creating a blueprint for course design," Assessment and Evaluation in Higher Education 43, no. 5 (2018): 840854 .

33 Litchfield dan Dempsey, "Authentic"

34 Craig Merrett, "Using case studies and build projects as authentic assessments in cornerstone courses," International Journal of Mechanical Engineering Education (2020). instructional"

35 Herrington dan Herrington, "Authentic"; Herrington dan Oliver, "An 36 Villarroel et al., "Authentic"

37 Mueller, "Authentic"

${ }^{38}$ Herrington dan Herrington, "Authentic" 
yang komprehensif..$^{39}$ Ketiga, pemberian umpan balik dalam AA dan asesmen lain dari guru untuk setiap siswa menyita banyak waktu guru, dan ini juga menjadi salah satu kelemahan AA yang terjawab secara tuntas. $^{40}$

Sementara itu, hambatan-hambatan dalam pelaksanaan AA adalah sebagai berikut. Pertama, kebijakan lembaga pendidikan tidak mendukung AA karena AA dianggap tidak praktis. ${ }^{41}$ Kedua, guru-guru tidak mendapatkan pelatihan yang memadai tentang $\mathrm{AA}^{42}$ Ini menyangkut literasi asesmen para guru di Indonesia dan negara-negara lain yang masih rendah ${ }^{43}$ dan perlu ditingkatkan. ${ }^{44}$ Guru cenderung menggunakan asesmen tradisional, seperti tes tertulis pilihan ganda, dan mereka enggan untuk memakai AA karena pelaksanaan AA memakan lebih banyak waktu, energi dan pikiran. ${ }^{45}$

AA dengan kelebihan, kekurangan dan hambatan pelaksanaannya ini dipakai untuk menilai proses pencapaian tujuan PAI dan capaian akhir tujuannya, yakni produk PAI yang dihasilkan siswa atau kinerja PAI siswa. PAI (tarbiyah) merupakan proses yang menyeluruh, melibatkan aktivitas fisik dan reflektif untuk menumbuhkembangkan dan mengubah fisik, kognisi, spiritualitas, moralitas dan emosi manusia ke arah yang positif. ${ }^{46}$

39 Samrat Ghosh et al., "Improving the validity and reliability of authentic assessment in seafarer education and training: a conceptual and practical framework to enhance resulting assessment outcomes," WMU Journal of Maritime Affairs 16, no. 3 (2017): 455-472.

40 Icy Lee, Pauline Mak, dan Rui Eric Yuan, "Assessment as learning in primary writing classrooms: An exploratory study," Studies in Educational Evaluation 62, no. April (2019): 72-81.

${ }^{41}$ Herrington dan Herrington, "Authentic"

42 Thomas C. Reeves, "Alternative assessment approaches for online learning environments in higher education," Journal of Educational Computing Research 23, no. 1 (2000): 101-111.

43 Fauzi Puji Anto Rahman, "Literasi Guru Sekolah Dasar terkait Asesmen," Jurnal Inovasi Pendidikan Dasar 1, no. 1 (2016): 9-14; Ricky Lam, "Teacher assessment literacy: Surveying knowledge, conceptions and practices of classroom-based writing assessment in Hong Kong," System 81 (2019): 78-89.

44 Inés Taylor et al., "Marking classwork in primary science: written feedback practices in state schools in Buenos Aires, Argentina," Assessment in Education: Principles, Policy and Practice 27, no. 3 (2020): 271-289.

45 Villarroel et al., "Authentic"

${ }^{46}$ Sahin, "Critical issues"; Imroatun Imroatun dan Ilzamudin Ilzamudin, "Sejarah Peristilahan Tarbiyah Dan Taklim Dalam Tinjauan Filsafat Pendidikan Islam," Ulumuddin: Jurnal Ilmu-ilmu Keislaman 10, no. 2 (Desember 29, 2020): 163-176. 
PAI memperhatikan kualitas proses pendidikan, tetapi harus lebih berorientasi pada kualitas lulusan dalam hal karakter (jujur, disiplin, mandiri, kerja keras, tahan banting), literasi, dan kemampuan berpikir logis. ${ }^{47}$ Tujuan dari PAI untuk menumbuhkembangkan seluruh komponen humanis dan menyelesaikan masalah-masalah sosial ${ }^{48}$ ini merupakan ibadah kepada Allah Swt. ${ }^{49}$ Di Indonesia, PAI di MI/SD, MTs/SMP, dan MA/SMA/SMK bertujuan untuk mencapai 4 kompetensi inti, yakni sikap spiritual, sikap sosial, pengetahuan, dan keterampilan. ${ }^{50}$ Artinya, PAI yang diselenggarakan di Indonesia mencakup seluruh komponen kemanusiaan yang penilaiannya tidak hanya menyasar ranah kognisi, tetapi juga ranahranah lainnya. PAI juga bertujuan melahirkan bukan hanya individuindividu Muslim, melainkan juga umat Islam yang utuh.

\section{B. Metode}

Untuk mencapai 3 tujuan penelitian yang telah disebutkan di atas, artikel ini telah menerapkan systematic literature review (SLR) atau metodologi penelitian pustaka sistematis (PPS). Patricia A. Alexander menetapkan 10 langkah dalam $\mathrm{PPS}^{51}$ yakni (1) mencari pertanyaan kritis yang penting untuk dikaji dengan metodologi penelitian pustaka, (2) mengajukan pertanyaan kritis yang belum terjawab, tetapi bisa dijawab, (3) menentukan kriteria-kriteria pustaka yang akan dicari dan diteliti, (4) menentukan kriteria-kriteria kualitas pustaka yang sudah dicari dan layak dan tidak layak untuk diteliti, (5) mengumpulkan data-data pokok, (6) mengumpulkan data-data lain yang relevan, (7) menentukan 2006).

47 Sutrisno, Pendidikan Islam yang Menghidupkan (Yogyakarta: Kota Kembang,

48 Mohamad Ali, Sodiq Azis Kuntoro, dan Sutrisno Sutrisno, "Pendidikan Berkemajuan: Refleksi Praksis Pendidikan K.H. Ahmad Dahlan," Jurnal Pembangunan Pendidikan: Fondasi dan Aplikasi 4, no. 1 (2016): 43-58.

49 Hibana, Sodiq A. Kuntoro, dan Sutrisno, "Pengembangan Pendidikan Humais Religius di Madrasah," Jurnal Pembangunan Pendidikan: Fondasi dan Aplikasi 3, no. 1 (2015): 19-30.

$5^{\circ}$ Kemenag RI, Surat Keputusan Direktur Jenderal Pendidikan Islam Nomor 5161 Tahun 2018 Tentang Petunjuk Teknis Hasil Belajar pada Madrasah Ibtidaiyah; Kemenag RI, Surat Keputusan Direktur Jenderal Pendidikan Islam Nomor 5162 Tahun 2018 Tentang Petunjuk Teknis Hasil Belajar pada Madrasah Tsanawiyah; Kemenag RI, Surat Keputusan Direktur Jenderal Pendidikan Islam Nomor 3751 Tahun 2018 Tentang Petunjuk Teknis Hasil Belajar pada Madrasah Aliyah.

${ }^{1}$ Patricia A. Alexander, "Methodological Guidance Paper: The Art and Science of Quality Systematic Reviews," Review of Educational Research 90, no. 1 (2020): 6-23. 
kemungkinan pengelompokan-pengelompokan data, (8) mengidentifikasi hasil-hasil penelitian yang bermakna, (9) menentukan pola-pola dan kecenderungan-kecenderungan, dan (10) memublikasikan kontribusi penelitian.

Langkah nomor 1 dan 2 telah dilakukan di atas dan telah dirumuskan 3 pertanyaan kritis penelitian, yakni (1) Bagaimana kegagalan pelaksanaan AA pada pelajaran PAI di sekolah-sekolah dasar dan menengah di Indonesia? (2) Mengapa kegagalan tersebut terjadi? (3) Apa implikasi dari kegagalan pelaksanaan AA pada pelajaran PAI di sekolahsekolah dasar dan menengah dan pada kaum Muslim? Selanjutnya, pada langkah nomor 3, pustaka-pustaka yang dicari dan diteliti ialah artikelatikel atau hasil-hasil penelitian tentang penilaian atau asesmen autentik dalam tentang pelajaran PAI di sekolah-sekolah dasar dan menengah. Artikel-artikel itu menjadi sumber data tentang pelaksanaan AA pada pelajaran PAI di sekolah-sekolah dasar dan menengah. Artikel-atikel atau hasil-hasil penelitian tersebut dicari di https://garuda.ristekbrin.go.id/ dan Google pada bulan Februari-Maret 2021. Kata-kata kunci untuk mencari artikel-artikel tersebut adalah "evaluasi agama Islam", "evaluasi pendidikan Islam”, "evaluasi pendidikan agama Islam”, “asesmen agama Islam", "asesmen pendidikan Islam", "asesmen pendidikan agama Islam”, "penilaian agama Islam", "penilaian pendidikan Islam", penilaian pendidikan agama Islam, "autentik agama Islam", dan "otentik agama Islam”. Dari hasil pencarian itu, ditemukan 120 artikel-atikel atau hasilhasil penelitian tentang penilaian atau asesmen autentik dalam pelajaran PAI di sekolah-sekolah dasar dan menengah.

Tabel 1. Jumlah Pustaka tentang Penelitian Empiris Pelaksanaan Asesmen Autentik di Sekolah Dasar dan Menengah Tahun 2014-2020

\begin{tabular}{|c|c|}
\hline Tahun Terbit & Jumlah Pustaka \\
\hline 2014 & 2 \\
\hline 2015 & 0 \\
\hline 2016 & 7 \\
\hline 2017 & 4 \\
\hline 2018 & 4 \\
\hline 2019 & 8 \\
\hline 2020 & 2 \\
\hline Jumlah & 27 \\
\hline
\end{tabular}


Pada langkah PPS nomor 4, kriteria pustaka yang diteliti ialah artikel-artikel atau hasil-hasil penelitian empiris tentang penilaian atau asesmen autentik dalam pelajaran PAI di sekolah-sekolah dasar dan menengah. Artikel-atikel atau hasil-hasil penelitian pustaka tidak diteliti sebab tidak menunjukkan bagaimana pelaksanaan penilaian atau asesmen autentik dalam pelajaran PAI di sekolah-sekolah dasar dan menengah. Dari 120 pustaka tersebut, hanya 27 (P1-P27) yang merupakan hasil penelitian empiris tentang pelaksanaan penilaian atau asesmen autentik dalam pelajaran PAI di sekolah-sekolah dasar dan menengah (SD, SMP, SMA, SMK), dan inilah yang diteliti. Dua puluh enam pustaka itu terbit pada tahun 2014-2020 (Tabel 1), sebab hanya itulah dokumen-dokumen yang ditemukan di https://garuda.ristekbrin.go.id/ dan Google pada bulan Februari-Maret 2021.

Langkah PPS nomor 5-10 sudah dilakukan dengan mengacu pada teori-teori yang dikemukakan sebelumnya. Data-data tentang pelaksanaan AA di sekolah-sekolah dasar dan menengah dikumpulkan dengan mencari 23 karakteristik AA pada setiap artikel atau hasil penelitian empiris tentang AA dan dengan mencari penyebab-penyebab kegagalan pelaksanaan AA dan implikasinya, serta data-data lain yang relevan. Data ihwal pelaksanaan AA dalam bentuk frekuensi dikelompokkan ke dalam 23 karakteristik atau kategori yang Becker sebut sebagai statistika semu (quasi statistics) untuk mendukung analisis kualitatif. ${ }^{52}$ Data dalam bentuk frekuensi setiap karakteristik yang muncul pustaka-pustaka yang diteliti dianalisis lebih dalam untuk menemukan perbedaan, ambiguitas, makna yang sebenarnya, pola-pola dan kecenderungankecenderungannya. $^{53}$ Data-data lain tentang penyebab kegagalan pelaksanaan AA dan implikasinya dianalisis dengan dikaitkan pada datadata lain yang relevan untuk mengungkap apa yang sebetulnya terjadi. Publikasi artikel ini merupakan langkah ke-10 yang dicetuskan oleh Alexander.

52 Joseph A. Maxwell, "Using numbers in qualitative research," Qualitative Inquiry 16, no. 6 (2010): 475-482.

53 Alexander, "Methodological" 


\section{Deskripsi dan Pembahasan}

Bagian ini mendeskripsikan dan membahas (1) kegagalan pelaksanaan AA pada pelajaran PAI di sekolah-sekolah dasar dan menengah di Indonesia, (2) penyebab kegagalan pelaksanaan AA tersebut dan (3) implikasi dari kegagalan pelaksanaan AA pada pelajaran PAI di sekolah-sekolah dasar dan menengah dan pada kaum Muslim. Kegagalan pelaksanaan AA pada pelajaran PAI di sekolah-sekolah dasar dan menengah terlihat pada sedikitnya karakteristik AA yang muncul pada pelaksanaan AA pada pelajaran PAI di sekolah-sekolah dasar dan menengah yang dilakukan oleh guru-guru PAI. Dua belas dari 23 karakteristik AA (52\%) tidak ditemukan pada 27 pelaksanaan AA (Tabel 2), sedangkan sebelas karakteristik AA lainnya ditemukan dalam pelaksanaan AA tersebut dengan frekuensi antara 1-11. Delapan karakteristik yang ditemukan 1 kali (paling sedikit) adalah konteks sosial, tugas yang membutuhkan waktu lama untuk menyelesaikannya, penerapan pengetahuan, keterampilan dan sikap, kreativitas, kolaborasi, indikator produk, keaktifan belajar, dan umpan balik. Dua karakteristik yang ditemukan 2 kali ialah konteks fisik/virtual dan. tugas yang berupa kegiatan riil yang sesuai dengan kegiatan dalam kehidupan nyata. Satu karakteristik yang ditemukan 4 kali ialah indikator tentang unjuk kerja. Satu karakteristik yang ditemukan 7 kali adalah menilai diri siswa sendiri. Satu karakteristik yang ditemukan 11 kali (paling banyak) ialah adanya rubrik. Pelaksanaan AA ini memiliki karakteristik AA antara 1-6, dan 14 pelaksanaan AA tidak mempunyai karakteristik AA (Tabel 3).

Karakteristik-karakteristik AA tidak banyak muncul sejak awal pelaksanaan AA yang dimulai dari menentukan konteks dan tugas asesmen. Karakteristik konteks fisik/virtual dan sosial hanya ada dalam 3 pelaksanaan AA, dan karakteristik tugas AA untuk siswa hanya terdapat 3 pelaksanaan AA juga. Alhasil, kegagalan pelaksanaa AA pada pelajaran PAI di sekolah-sekolah dasar dan menengah dimulai sejak tahap awal perencanaan AA. Kalau sedari tahap awal guru-guru tidak menentukan konteks fisik/virtual dan sosial yang sesuai dengan kehidupan nyata, dan juga tidak memberikan kepada siswa tugas yang berupa kegiatan riil 
kehidupan nyata, menyelesaikan masalah kehidupan, menantang, kompleks, tidak terstruktur dan membutuhkan waktu lama bagi siswa untuk menyelesaikannya, maka AA tidak akan terlaksana. Inilah yang terjadi dalam praktik AA pada pelajaran PAI di sekolah-sekolah dasar dan menengah di Indonesia tahun 2014-2020.

Uniknya, meskipun praktik-praktik AA di sekolah-sekolah dasar dan menengah itu memiliki sedikit sekali dan bahkan tidak memiliki karakteristik AA, para penelitinya tidak pernah menyimpulkan bahwa pelaksanaan AA di sekolah-sekolah dasar dan menengah yang ditelitinya itu gagal. Mereka berkesimpulan pelaksanaan AA "cukup baik" (P2), "sesuai dengan peraturan menteri" (P3), "sudah baik" (P6), "berjalan dengan baik" ( $\left.\mathrm{P}_{7}\right)$, dan "tidak maksimal" ( $\mathrm{P}_{4}$ ). Sebagian besar peneliti itu (23/88,46\% peneliti) tidak mengacu pada teori-teori dan karakteristikkarakteristik AA dari ahli-ahli AA seperti Grant Wiggins, Fred M. Newmann, Jan Herrington, Anthony Herrington, Judith T. M. Gulikers, Kevin Ashford-Rowe, Jon Mueller, Veronica Villarroel, Brenda C. Litchfield, dan John V. Dempsey. Selain itu, hanya 1 peneliti (P3) mengacu pada konsep AA pada Peraturan Menteri Pendidikan dan Kebudayaan Nomor 104 Tahun 2014 Tentang Penilaian Hasil Belajar oleh Pendidik pada Pendidikan Dasar dan Pendidikan Menengah. Kebanyakan peneliti tersebut tidak membekali penelitiannya dengan teori-teori AA yang memadai, dan ini bukti nyata dari kegagalan pelaksanaan AA pada pelajaran PAI di sekolah-sekolah dasar dan menengah di Indonesia.

Kegagalan pelaksanaan AA ini, menurut para peneliti itu, disebabkan oleh 4 hal, yakni (1) ketidaksiapan guru, (2) kurangnya sosialisasi dan pelatihan AA untuk para guru, (3) keterbatasan waktu dan tenaga guru, dan (4) kerumitan AA. P9 mengatakan guru "kurang siap" untuk melaksanakan AA, dan P10 menulis "pengetahuan guru terbatas" tentang AA. P1 menyatakan "kurang sosialisasi" AA, sementara P2, P6, P8 dan P18 menambahkan "kurangnya pelatihan" AA bagi guru, dan P3 mengimbuhkan "pelatihannya teoretis", bukan praktis. $\mathrm{P}_{5}$ dan P10 mengatakan "terlalu banyak siswa" (40 siswa), "guru sudah tua", dan "banyak tugas guru", sehingga guru gagal melaksanakan AA dengan baik. 
Guru-guru tidak mempunyai cukup waktu untuk merencanakan dan mempraktikkan AA secara lengkap. Kemudian, P2 dan P3 menyebutkan bahwa guru-guru memandang AA itu "rumit" dan sulit diterapkan. Empat penyebab kegagalan pelaksanaan AA tersebut ditulis oleh para peneliti itu.

Dalam bahasa yang lebih tegas, ketidaksiapan guru dan keterbatasan pengetahuan guru, ketika dikaitkan dengan sedikitnya karakteristik AA dalam praktik AA mereka, berarti bahwa guru tidak menguasai dan tidak memahami AA. Namun, guru tidak bisa disalahkan begitu saja karena sosialisasi dan pelatihan AA kepada guru juga kurang. Untuk belajar sendiri tentang AA, waktu dan tenaga guru pun terbatas, apalagi dengan tuntutan untuk mengajar minimal sebanyak 24 jam pelajaran sebagaimana dalam Undang-Undang Nomor 14 Tahun 2005 Tentang Guru dan Dosen Pasal 35 Ayat (2). ${ }^{54}$ Kalau pun guru memahami AA dan melaksanakannya dengan lengkap, keterbatasan waktu dan tenaga mereka dengan banyaknya jumlah siswa per kelas yang mereka ajar tetap menjadi kendala untuk menyimak laporan kemajuan tugas siswa dan memberikan umpan balik kepada setiap siswa atau kelompok siswa secara rutin.

Tabel 2. Frekuensi Karakteristik Asesmen Autentik pada Pelajaran Pendidikan Agama Islam di Sekolah Dasar dan Menengah di Indonesia Tahun 2014-2020

\begin{tabular}{llr}
\hline Karakteristik Asesmen Autentik & Frekuensi \\
\hline A. & Konteks & 2 \\
\hline 1. Fisik/Virtual & 1 \\
\hline 2. Sosial & 2 \\
\hline B. & Tugas untuk Siswa & \\
\hline 3. Kegiatan riil & \\
\hline 4. Menyelesaikan masalah & \\
\hline 5. Menantang & 1 \\
\hline 6. Kompleks & \\
\hline 7. Tidak terstruktur & 1 \\
\hline 8. Membutuhkan waktu lama & 1 \\
\hline C. & Aktivitas Siswa & \\
\hline 9. Menerapkan keterampilan berpikir tingkat tinggi & \\
\hline 10. Menerapkan pengetahuan, keterampilan \& sikap & \\
\hline 11. Mengambil keputusan & \\
\hline 12. Berpartisikasi dalam kegiatan riil & \\
\hline 13. Kreatif & Berkolaborasi & \\
\hline
\end{tabular}

54 Republik Indonesia, Undang-Undang Republik Indonesia nomor 14 Tahun 2005 Tentang Guru dan Dosen, 2005. 


\begin{tabular}{lr}
\hline & \\
\hline 15. Menilai diri sendiri & 7 \\
\hline 16. Mempresentasikan kinjera/produknya secara lisan/tulisan & \\
\hline D. Indikator Assesmen & 1 \\
\hline 17. Produk & 4 \\
\hline 18. Unjuk Kerja & 11 \\
\hline 19. Rubrik & 1 \\
\hline 20. Beragam indikator pemelajaran & 1 \\
\hline 21. Keaktifan belajar & 34 \\
\hline 22. Penurunan plagiarisme & \\
\hline
\end{tabular}

Menyimak laporan kemajuan tugas siswa dan memberikan umpan balik kepada setiap siswa atau kelompok siswa secara rutin merupakan salah satu "kerumitan" AA di tengah-tengah budaya tes tulis dan lisan. ${ }^{55}$ Kerumitan ini disebabkan barangkali oleh budaya tes tulis dan lisan yang masih dominan dan juga oleh AA yang memang mempunyai banyak karakteristik. Tes tulis dan lisan sebagai asesmen tradisional sudah biasa dilaksanakan oleh guru dan siswa dan lebih mudah dilakukan daripada AA. Sehingga, kebiasaan untuk melaksanakan tes di satu sisi dan kebaruan AA dalam budaya tes tulis dan lisan yang dominan di sisi lain menjadikan AA dipandang "rumit" oleh guru. Namun, 23 karakteristik AA mungkin juga menyumbang "kerumitan" tersendiri. Sebenarnya, AA tidak perlu dipertentangkan dengan asesmen tradisional, sebab Mueller berpendapat bahwa AA tidak menggantikan asesmen tradisional, tetapi melengkapinya.$^{56} \mathrm{AA}$ dan asesmen tradisional, dilakukan semua.

"Kerumitan" dan kegagalan pelaksanaan AA pada pelajaran PAI di sekolah-sekolah dasar dan menengah memiliki implikasi jangka pendekdan sebagai catatan, belum ada penelitian tentang implikasi jangka panjang AA. Dalam 27 pustaka, tidak disebutkan secara eksplisit apa implikasi dari kegagalan pelaksanaan AA. Namun, dalam pustaka-pustaka itu dikatakan bahwa guru-guru PAI hanya melakukan tes tulis, tes lisan dan tes praktik yang didominaasi ranah kognitif. Tes praktik-misalnya menghafal surat-surat dalam Al-Qur'an, wudu dan salat-masih dominan dengan ranah kognitif dan kurang menantang. Tugas asesmen yang lebih

55 Christopher J. Harrison et al., "Changing the culture of assessment: the dominance of the summative assessment paradigm," BMC Medical Education 17, no. 1 (2017): 1-14.

${ }^{6}$ Mueller, "Authentic" 
menantang dan riil dalam konteks salat, misalnya, adalah bagaimana menyelesaikan masalah sebagian umat Islam yang jarang salat wajib lima waktu berjamaah di masjid. Implikasi jangka pendek dari budaya tes tulis, lisan dan praktik yang didominasi ranah kognitif ialah siswa cenderung menerima, bukan mengonstruksi pengetahuan PAI, dan guru mentransfernya. ${ }^{57}$ Dengan perkataan lain, PAI menjadi bersifat kognitif, tetapi tidak menjadi perilaku dan gerakan peradaban. Padahal, AA berlandaskan teori belajar konstruktivisme ${ }^{58}$ sedangkan asesmen tradisional berdasarkan teori kognitivisme. ${ }^{59}$

Tabel 3. Jumlah Karakteristik Asesmen Autentik pada Pustaka yang Diteliti

\begin{tabular}{|c|c|}
\hline Pustaka & Jumlah Karakteristik AA \\
\hline 1 & $\mathrm{O}$ \\
\hline 2 & 5 \\
\hline 3 & $\mathrm{O}$ \\
\hline 4 & 1 \\
\hline 5 & $\mathrm{O}$ \\
\hline 6 & 4 \\
\hline 7 & 5 \\
\hline 8 & 2 \\
\hline 9 & $\mathrm{O}$ \\
\hline 10 & $\mathrm{O}$ \\
\hline 11 & 3 \\
\hline 12 & $\mathrm{O}$ \\
\hline 13 & $\mathrm{O}$ \\
\hline 14 & 0 \\
\hline 15 & 2 \\
\hline 16 & $\mathrm{O}$ \\
\hline 17 & $\mathrm{O}$ \\
\hline 18 & 1 \\
\hline 19 & $\mathrm{O}$ \\
\hline 20 & $\mathrm{O}$ \\
\hline 21 & 6 \\
\hline 22 & $\mathrm{O}$ \\
\hline 23 & $\mathrm{O}$ \\
\hline 24 & 1 \\
\hline 25 & 1 \\
\hline 26 & 1 \\
\hline 27 & 2 \\
\hline Jumlah & 34 \\
\hline
\end{tabular}

57 Sin Wang Chong, "Three Paradigms of Classroom Assessment: Implications for Written Feedback Research," Language Assessment Quarterly 15, no. 4 (2018): 330-347. ${ }^{8}$ Celia Booyse dan Rajendra Chetty, "The significance of constructivist classroom practice in national curricular design," Africa Education Review 13, no. 1 (2016): 135149.

59 Ibid. 
Selain itu, siswa-siswa yang belajar PAI itu tidak mencapai tujuan AA. Mereka tidak terdidik dan tidak terlatih untuk mengidentifikasi dan berpartisipasi dalam konteks kehidupan riil, untuk menerapkan pengetahuan, keterampilan berpikir tingkat tinggi dan sikap dalam kehidupan riil, untuk menyelesaikan masalah-masalah umat Islam yang kompleks, dan untuk berkolaborasi atau bekerja sama. Implikasi jangka panjang dari semua ini bagi kaum Muslim di Indonesia sangat menarik untuk diteliti dan dicermati.

Jadi, secara ringkas, pelaksanaan AA pada pelajaran PAI di sekolah-sekolah dasar dan menengah di Indonesia terbukti gagal, dan bukti dari kegagalan ini ialah sedikitnya karakteristik AA yang terdapat pada praktik-praktik AA dalam 27 hasil penelitian tersebut di atas. Empat penyebab dari kegagalan ini ialah (1) ketidaksiapan guru, (2) kurangnya sosialisasi dan pelatihan AA untuk para guru, (3) keterbatasan waktu dan tenaga guru, dan (4) kerumitan AA. Kegagalan pelaksanaan AA berimplikasi pada (1) siswa-siswa yang menjadi sekadar penerima pengetahuan, bukan pengonstruknya, (2) siswa-siswa yang tidak terdidik untuk menyelesaikan masalah-masalah kaum Muslim yang kompleks dengan menerapkan keterampilan-keterampilan berpikir tingkat tinggi, pengetahuan dan sikap mereka, dan (3) PAI yang bersifat kognitif ketimbang menjadi pelajaran perilaku dan gerakan peradaban. Inilah kegagalan pelaksanaan AA pada pelajaran PAI, penyebabnya dan implikasinya.

Kegagalan pelaksanaan AA ini merupakan bagian dari praktik PAI yang tidak autentik, lantaran AA merupakan bagian dari pemelajaran autentik (PA). ${ }^{60}$ Sulit dipahami bahwa guru melaksanakan AA tanpa melakukan PA. Ide PA mengemuka karena terjadi pemisahan antara pengetahuan (knowing) dan tindakan (doing). Sekolah dan perguruan tinggi mengajarkan lebih banyak pengetahuan daripada tindakan, sehingga lulusannya cenderung memiliki pengetahuan saja, bukan menerapkannya. Agama Islam pun dipandang dan diajarkan utamanya

6o Herrington dan Oliver, "An instructional” 
sebagai pengetahuan dan ritual ${ }^{61}$ daripada sebagai praktik keagamaan yang hidup. PAI juga belum menghidupkan siswa untuk menumbuhkembangkan dirinya dan kaum Muslim. ${ }^{62}$

Namun, kegagalan pelaksanaan AA dan PAI yang belum menghidupkan ini berada pada satu fase dari perjalanan panjang reformasi pendidikan Islam. Reformasi pendidikan Islam di Indonesia dan di dunia menyangkut tiga hal, yakni (1) kemunculan madrasah atau sekolah di luar pesantren untuk menyelenggarakan pendidikan Islam, (2) integrasi dan keseimbangan antara pendidikan agama dan modernisasi, dan (3) keterbukaan pikiran para tokoh pendidikan Islam terhadap kemajemukan dan inovasi di dalam dan luar kalangan Muslim agar pendidikan Islam selalu relevan dengan perkembangan masyarakat. ${ }^{63}$ Semangat dan upaya guru, sekolah dan pemerintah untuk melaksanakan AA dan PAI yang menghidupkan, meskipun belum berhasil, sedang berjalan menuju reformasi pendidikan Islam supaya PAI senantiasa relevan dengan perkembangan masyarakat.

Hasil penelitian ini berbeda dengan hasil-hasil penelitian lain tentang pelaksanaan AA pada pelajaran PAI di sekolah-sekolah dasar dan menengah di Indonesia. Penelitian-penelitian lain menyimpulkan bahwa pelaksanaan-pelaksanaan AA berjalan dengan baik, ${ }^{64}$ cukup baik, ${ }^{65}$ dan tidak maksimal. ${ }^{66}$ Namun, penelitian ini secara tegas menyimpulkan bahwa dengan bukti-bukti di atas, pelaksanaan AA pada pelajaran PAI di sekolah-sekolah dasar dan menengah di Indonesia tahun 2014-2020 telah gagal. Penyebabnya adalah guru-guru PAI yang tidak memahami AA karena kurangnya sosialisasi dan pelatihan AA. Implikasinya ialah siswa-

${ }^{61}$ Alfi Mar'atul Khasanah, "Peran Guru PAI Dalam Pembentukan Akhlak Peserta Didik," in Pendidikan Agama Islam Dan Penguatan Karakter Religius Dalam Menghadapi Era Revolusi Industri 4.o, ed. Lilik Nur Kholidah (Malang: Lembaga Pengembangan Pendidikan dan Pembelajaran Universitas Negeri Malang, 2019).

${ }^{62}$ Sutrisno, Pendidikan

63 Azyumardi Azra, "Reforms in Islamic Education: A Global Perspective Seen from the Indonesian Case," in Reforms in Islamic Education: International Perspectives, ed. Charlene Tan (London: Bloomsbury Academic, 2015).

64 Berampu, "Penerapan"; Putra, "Penilaian"

65 Arif, "Penerapan"

66 Abdullah, "Implementasi" 
siswa yang tidak mencapai tujuan AA. Ini temuan baru yang memberi kontribusi bagi khazanah penelitian AA dalam PAI.

Dengan kegagalan pelaksanaan AA pada pelajaran PAI di sekolahsekolah dasar dan menengah, perlu diperbaiki hal ihwal (1) sosialisasi dan pelatihan AA, (2) penyelenggaraan PAI secara umum, dan (3) penelitian AA. Sosialisi dan pelatihan AA terutama bagi guru PAI perlu dilakukan dengan tata cara tertentu sampai para guru PAI itu bisa benar-benar melaksanakan AA secara optimal. Pelatihan AA ini perlu dibarengi dengan pelatihan PA karena AA merupakan bagian dari PA. PA dan AA luring dan daring tidak hanya berkaitan dengan penerapan Kurikulum 2013, melainkan menjadi salah satu asesmen alternatif.

Tak hanya guru, para peneliti pun perlu membekali diri dengan teori-teori AA dan PA secara komprehensif, mengkritisinya dan mengembangkan teori-teori AA dan PA dalam konteks pendidikan dan kehidupan Islam Indonesia. Artikel ini baru sedikit mengkritisinya AA yang mengindustrialisasikan perguruan tinggi. Kritik-kritik lain perlu diarahkan pada AA dan PA berdasarkan konteks pendidikan dan kehidupan Islam Indonesia untuk kemudian membangun teori-teori AA dan PA yang lebih baru.

\section{Penutup}

Temuan terpenting dari penelitian ini ialah bahwa pelaksanaan AA pada pelajaran PAI di sekolah-sekolah dasar dan menengah di Indonesia selama 7 tahun (2014-2020) telah gagal. Apa yang dinamakan pelaksanaan AA oleh guru-guru PAI itu hanya mengandung sedikit sekali karakteristik AA yang dirumuskan oleh para ahli AA. Para guru PAI itu dan sebagian besar penelitinya tidak menguasai dan tidak memahami AA serta gagal melakukan AA. Implikasinya, siswa-siswa tidak terdidik dan tidak terlatih untuk berpartisipasi dalam konteks kehidupan riil, untuk menerapkan pengetahuan, keterampilan berpikir tingkat tinggi dan sikap dalam kehidupan riil, untuk mengidentifikasi dan menyelesaikan masalahmasalah umat Islam yang kompleks, untuk berkolaborasi, dan untuk mengonstruksi pengetahuan. 
Namun, artikel ini mempunyai keterbatasan karena menggunakan metodologi penelitian pustaka dengan meneliti hasil-hasil penelitian tentang pelaksanaan AA. Alhasil, pelaksanaan-pelaksanaan AA di luar hasil-hasil penelitian tersebut tidak tercakup dan tidak dianalisis dalam artikel ini. Maka, artikel ini perlu dilengkapi dengan penelitian empiris tentang pelaksanaan AA pada pelajaran PAI di sekolah, madrsah serta pesantren di Indonesia dalam skala yang luas. Pun, sebagaimana telah disebutkan sebelumnya, dibutuhkan penelitian-penelitian empiris tentang implikasi jangka panjang (learning outcome) dari pelaksanaan AA pada pelajaran PAI dan juga pelajaran-pelajaran lain.

\section{Daftar Pustaka}

Abdullah. "Implementasi Penilaian Autentik Kurikulum 2013 Pada Pembelajaran Pendidikan Agama Islam Di Madrasah Tsanawiyah Negeri 2 Palangka Raya." FITRAH:Jurnal Kajian Ilmu-ilmu Keislaman 2, no. 2 (2017): 59.

Alexander, Patricia A. "Methodological Guidance Paper: The Art and Science of Quality Systematic Reviews.” Review of Educational Research 90, no. 1 (2020): 6-23.

Alhamuddin. "Implementasi Penilaian Otentik dalam Pembelajaran PAI Berbasis Multiple Intelligences di Sekolah Dasar Islam Terpadu Buahati Jakarta." Ta'dib 5, no. 1 (2016): 1-10.

Ali, Mohamad, Sodiq Azis Kuntoro, dan Sutrisno Sutrisno. "Pendidikan Berkemajuan: Refleksi Praksis Pendidikan K.H. Ahmad Dahlan.” Jurnal Pembangunan Pendidikan: Fondasi dan Aplikasi 4, no. 1 (2016): 43-58.

Ansor, Halimi. "Strategi Penilaian Autentik Kurikulum 2013 Pada Mata Pelajaran Pendidikan Agama Islam Dan Budi Pekerti (Studi Kasus Di SMP Negeri 1 Pabuaran Kabupaten Cirebon).” Oasis: Jurnal Ilmiah Kajian Islam 3, no. 1 (2018): 57-72.

Archer, Melenie, Dawn A. Morley, dan Jean-Baptiste R. G. Souppez. "Real World Learning and Authentic Assessment." In Applied Pedagogies for Higher Education Real World Learning and Innovation across the Curriculum. Cham: Palgrave Macmillan, 2021.

Arif, Saiful. "Penerapan Penilaian Autentik Pada Mata Pelajaran PAI Di SMPN 1 Pamekasan.” NUANSA: Jurnal Penelitian Ilmu Sosial dan Keagamaan Islam 11, no. 2 (2014): 235-262.

Ashford-Rowe, Kevin, Janice Herrington, dan Christine Brown. "Establishing the critical elements that determine authentic assessment." Assessment and Evaluation in Higher Education 39, no. 2 (2014): 205-222.

Astuti, Efi Tri. "Problematika Implementasi Penilaian Autentik Kurikulum 2013 Dalam Pembelajaran Pendidikan Agama Islam Di SD Negeri Ploso I Pacitan." Al-Idaroh 1, no. 2 (2017): 18-41. 
Azra, Azyumardi. "Reforms in Islamic Education: A Global Perspective Seen from the Indonesian Case." In Reforms in Islamic Education: International Perspectives, diedit oleh Charlene Tan. London: Bloomsbury Academic, 2015.

Berampu, Jainuri. "Penerapan Penilaian Autentik Dalam Penilaian Aspek Sikap Bidang Studi PAI di MTs Negeri 2 Medan.” Universitas Islam Negeri Sumatera Utara, 2016.

Booyse, Celia, dan Rajendra Chetty. "The significance of constructivist classroom practice in national curricular design.” Africa Education Review 13, no. 1 (2016): 135-149.

Bosnakis, Alison Penelope. "The Bigger Picture: Authentic Assessment and Visual Literacy: Applying a Nordic Approach to an Australian Context." In Reflective Practice in Teaching Pre-service Teachers and the Lens of Life Experience, diedit oleh Gretchen Geng, Pamela Smith, Paul Black, Yoshi Budd, dan Leigh Disney. Singapore: Springer Singapore, 2019.

Chong, Edmund Jun Meng, Jessica Shih Wei Lim, Yuchan Liu, Yvonne Yen Lin Lau, dan Vivien Xi Wu. "Improvement of learning domains of nursing students with the use of authentic assessment pedagogy in clinical practice." Nurse Education in Practice 20 (2016): 125130 .

Chong, Sin Wang. "Three Paradigms of Classroom Assessment: Implications for Written Feedback Research." Language Assessment Quarterly 15, no. 4 (2018): 330-347.

Ellis, Cath, Karen van Haeringen, Rowena Harper, Tracey Bretag, Ian Zucker, Scott McBride, Pearl Rozenberg, Phil Newton, dan Sonia Saddiqui. "Does authentic assessment assure academic integrity? Evidence from contract cheating data." Higher Education Research and Development o, no. o (2019): 1-16.

Ghosh, Samrat, Marcus Bowles, Dev Ranmuthugala, dan Ben Brooks. "Improving the validity and reliability of authentic assessment in seafarer education and training: a conceptual and practical framework to enhance resulting assessment outcomes." $W M U$ Journal of Maritime Affairs 16, no. 3 (2017): 455-472.

Gulikers, J., Bastiaens, T., \& Kirschner, P. "A Five-Dimensional Framework for Authentic Assessment.” Educational Technology Research and Development 52, no. 3 (2004): 67-86.

Harrison, Christopher J., Karen D. Könings, Lambert W.T. Schuwirth, Valerie Wass, dan Cees P.M. Van der Vleuten. "Changing the culture of assessment: the dominance of the summative assessment paradigm.” BMC Medical Education 17, no. 1 (2017): 1-14.

Herrington, J., dan A. Herrington. "Authentic conditions for authentic assessment: Aligning task and assessment." In Proceedings of the 29th HERDSA Annual Conference. Milperra: Higher Education Research and Development Society of Australasia, Inc, 2006.

Herrington, Jan, dan Anthony Herrington. "Authentic assessment and multimedia: How university students respond to a model of authentic assessment." International Journal of Phytoremediation 21, no. 1 (1998): 305-322. 
Herrington, Jan, dan Ron Oliver. "An instructional design framework for authentic learning environments." Educational Technology Research and Development 48, no. 3 (2000): 23-48.

Hibana, Sodiq A. Kuntoro, dan Sutrisno. "Pengembangan Pendidikan Humais Religius di Madrasah.” Jurnal Pembangunan Pendidikan: Fondasi dan Aplikasi 3, no. 1 (2015): 19-30.

Imroatun, Imroatun, dan Ilzamudin Ilzamudin. "Sejarah Peristilahan Tarbiyah Dan Taklim Dalam Tinjauan Filsafat Pendidikan Islam.” Ulumuddin : Jurnal Ilmu-ilmu Keislaman 10, no. 2 (Desember 29, 2020): 163-176.

Jopp, Ryan. "A case study of a technology enhanced learning initiative that supports authentic assessment." Teaching in Higher Education o, no. o (2019): 1-17.

Kemenag RI. Surat Keputusan Direktur Jenderal Pendidikan Islam Nomor 3751 Tahun 2018 Tentang Petunjuk Teknis Hasil Belajar pada Madrasah Aliyah, 2018.

---. Surat Keputusan Direktur Jenderal Pendidikan Islam Nomor 5161 Tahun 2018 Tentang Petunjuk Teknis Hasil Belajar pada Madrasah Ibtidaiyah, 2018.

--_. Surat Keputusan Direktur Jenderal Pendidikan Islam Nomor 5162 Tahun 2018 Tentang Petunjuk Teknis Hasil Belajar pada Madrasah Tsanawiyah, 2018.

Khasanah, Alfi Mar'atul. "Peran Guru PAI Dalam Pembentukan Akhlak Peserta Didik." In Pendidikan Agama Islam Dan Penguatan Karakter Religius Dalam Menghadapi Era Revolusi Industri 4.o, diedit oleh Lilik Nur Kholidah. Malang: Lembaga Pengembangan Pendidikan dan Pembelajaran Universitas Negeri Malang, 2019.

King, M. Bruce, Fred M. Newmann, dan Dana L. Carmichael. "Authentic intellectual work: Common standards for teaching social studies." Social Studies Today: Research and Practice: Second Edition, no. April (2015): 53-64.

Kosim, Nanang. "Implementasi Penilaian Autentik Kurikulum 2013 dalam Mata Pelajaran Pendidikan Agama Islam dan Budi Pekerti di SMPN 6 Surabaya." Universitas Islam Negeri Sunan Ampel Surabaya, 2014.

Lam, Ricky. "Teacher assessment literacy: Surveying knowledge, conceptions and practices of classroom-based writing assessment in Hong Kong." System 81 (2019): 78-89.

Lee, Icy, Pauline Mak, dan Rui Eric Yuan. "Assessment as learning in primary writing classrooms: An exploratory study." Studies in Educational Evaluation 62, no. April (2019): 72-81.

Litchfield, Brenda C., dan John V. Dempsey. "Authentic Assessment of Knowledge, Skills, and Attitudes." New Directions For Teaching And Learning 142 (2015).

Marfuah, Anis, dan Febriza Febriza. "Penilaian Autentik pada Pembelajaran Pendidikan Agama Islam (PAI) di Sekolah dan Perguruan Tinggi." Fondatia 3, no. 2 (2019): 35-58.

Maxwell, Joseph A. "Using numbers in qualitative research." Qualitative Inquiry 16, no. 6 (2010): 475-482. 


\section{Kegagalan Asesmen Autentik pada \\ Pelajaran PAI di Sekolah Dasar dan Menengah}

Merrett, Craig. "Using case studies and build projects as authentic assessments in cornerstone courses." International Journal of Mechanical Engineering Education (2020).

Mueller, Jon. "Authentic Assessment Toolbox."

Nurmikko-Fuller, Terhi, dan Ian E. Hart. "Constructive alignment and authentic assessment in a media-rich undergraduate course." Educational Media International oo, no. oo (2020): 1-16.

Nurrohim, Hadi. "Implementasi Penilaian Otentik Bidang Studi PAI dan Budi Pekerti di SMAN Dempet Jawa Tengah.” At-Tajdid 01, no. 02 (2017).

Putra, Novialdi. "Penilaian Autentik Mata Pelajaran Pendidikan Agama Islam Dan Budi Pekerti Di SMP Negeri 4 Pariaman.” al-fikrah: Jurnal Manajemen Pendidikan 3, no. 2 (2016): 203.

Rahman, Fauzi Puji Anto. "Literasi Guru Sekolah Dasar terkait Asesmen." Jurnal Inovasi Pendidikan Dasar 1, no. 1 (2016): 9-14.

Reeves, Thomas C. "Alternative assessment approaches for online learning environments in higher education." Journal of Educational Computing Research 23, no. 1 (2000): 101-111.

Republik Indonesia. Undang-Undang Republik Indonesia nomor 14 Tahun 2005 Tentang Guru dan Dosen, 2005.

Sahin, Abdullah. "Critical issues in islamic education studies: Rethinking islamic and western liberal secular values of education." Religions 9, no. 11 (2018).

Setiawan, Dika. "Pendekatan Saintifik Dan Penilaian Autentik Untuk Meningkatkan Mutu Pembelajaran Pendidikan Agama Islam.” $A L$ ASASIYYA: Journal Of Basic Education 1, no. 2 (2017): 34-46.

Sugiarti, Aprilia Tri. "Penerapan Penilaian Autentik dalam Pembelajaran Pendidikan Agama Islam Kelas X di SMAN 3 Yogyakarta." Universitas Islam Negeri Sunan Kalijaga Yogyakarta, 2016.

Sulistiati, Sulistiati. "Kompetensi Guru Pendidikan Agama Islam dalam Penilaian Autentik di SMA Negeri 1 Arga Makmur." Al-Bahtsu: Jurnal Penelitian Pendidikan Islam 2, no. 1 (2017): 143-154.

Suparjo. "Dinamika Perubahan Paradigma Pendidikan: Studi tentang Kesiapan Guru Pendidikan Agama Islam di SD/MI di Wilayah Kabupaten Banyumas dalam Menerapkan Pendekatan Pembelajaran Saintifik dan Penilaian Otentik Kurikulum 2013.” Jurnal Penelitian Agama 15, no. 2 (2014).

Susanti, Riri. "Implementasi Penilaian Autentik Pada Mata Pelajaran Pendidikan Agama Islam Dan Budi Pekerti.” al-fikrah: Jurnal Manajemen Pendidikan 4, no. 1 (2016): 55.

Sutrisno. Pendidikan Islam yang Menghidupkan. Yogyakarta: Kota Kembang, 2006.

Taylor, Inés, Manuel Sánchez, Mariana Luzuriaga, María Eugenia Podestá, dan Melina Furman. "Marking classwork in primary science: written feedback practices in state schools in Buenos Aires, Argentina." Assessment in Education: Principles, Policy and Practice 27, no. 3 (2020): 271-289.

Umami, Muzlikhatun. "Penilaian Autentik Pembelajaran Pendidikan Agama Islam dan Budi Pekerti dalam Kurikulum 2013.” Jurnal 
Kependidikan 6, no. 2 (2018): 222-232.

Villarroel, Verónica, Susan Bloxham, Daniela Bruna, Carola Bruna, dan Constanza Herrera-Seda. "Authentic assessment: creating a blueprint for course design." Assessment and Evaluation in Higher Education 43, no. 5 (2018): 840-854.

Wulansari, Zakiyah. "Pendidikan Agama Islam Dan Budi Pekerti Kurikulum 2013." Attarbiyah I, no. 1 (2016): 29-58.

Yudistiro, Irfan Murdianto. "Implementasi Penilaian Autentik pada Mata Pelajaran Pendidikan Agama Islam dan Budi Pekerti (Studi Multisitus di SMP Negeri 10 Malang dan SMP Brawijaya Smart School Malang).” Universitas Islam Negeri Maulana Malik Ibrahim Malang Indonesia, 2019. 